\title{
Exploring the Role of Ownership in International Entrepreneurship: How does Ownership Affect Internationalisation of Polish Firms?
}

\author{
Krzysztof Wach
}

\begin{abstract}
A B S T R A C T
Objective: The article focuses on the role of ownership in the process of entrepreneurial internationalisation of the firm. The main objective of the article is to verify whether and how ownership impacts on the level of internationalisation.

Research Design \& Methods: The study elaborates on three dimensions of ownership, which are ownership structure (foreign vs. domestic), family ownership and the characteristics of the owner (age, sex, global mindset and knowledge - the last two measured on a 5-point Likert scale). The sample of 190 internationalised Polish businesses were used in order to verify the assumed hypotheses.

Findings: The investigated firms operating in Poland of foreign ownership are more internationalised, measured by TNI, than those of domestic capital only. As a general rule, the investigated non-family firms are more internationalised than family firms as for the average TNI value. International attitude of the entrepreneur-owner affect the level of internationalisation: the higher values of attitude index, the higher values of TNI. Neither the age nor the sex of the entrepreneur affect the level of internationalisation.

Implications \& Recommendations: it is obvious that knowledge is one of the key factors affecting the internationalisation, especially market choices, entry modes as well as the speed of internationalisation. Although much has been done in this field, but it still needs further and deeper investigations.
\end{abstract}

Contribution \& Value Added: The current study and its findings indicate that ownership is one of key aspects relevant for explaining the internationalisation of firms, but its impact on firms' international behaviour is somewhat equivocal.

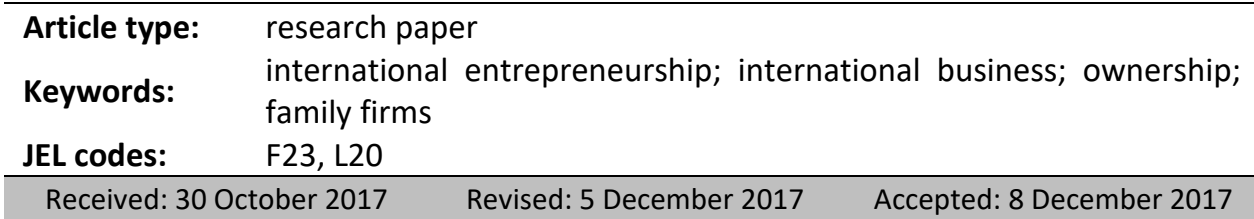

\section{Suggested citation:}

Wach, K. (2017). Exploring the Role of Ownership in International Entrepreneurship: How does Ownership Affect Internationalisation of Polish Firms?. Entrepreneurial Business and Economics Review, 5(4), 205-224. http://doi.org/10.15678/EBER.2017.050410 


\section{INTRODUCTION}

Ownership plays a special role in international business, and it can be a factor stimulating the internationalisation of firms, however, ownership can be researched into from the trichotomous perspective.

Firstly, ownership structure affects internationalisation, especially in two poles, namely foreign versus domestic ownership (Anil, Tatoglu, \& Ozkasap, 2014; Larimo \& Arslan, 2013), however, ownership can affect internationalisation in different ways depending on the various ownership-stake-related aspects, thus these issues should be under careful empirical investigations. This paper tries to verify basic prior results linking ownership structure and internationalisation, but taking Polish economy as an example of emerging markets.

Secondly, for a few decades, ownership has also been discussed from the family perspective (Wiklund, Nordqvist, Hellerstedt, \& Bird, 2013; Sciascia, Mazzola, Astrachan, \& Pieper, 2012), distinguishing a separate research domain (family entrepreneurship or family business). Only two reviews of empirical studies have been published recently, nevertheless with no consensus on whether family ownership restrains or facilitates their internationalisation (Kontinen \& Ojala, 2010; Pukall \& Calabrò, 2014). From such a perspective, this article facilities to explore and disentangle the influence of familiness on the internationalisation (Merono, Monreal-Perez, \& Sanchez-Marin, 2015).

Thirdly, ownership is also a certain element of entrepreneurship research, where it is usually reduced to the characteristics of the owner (Kurek \& Rachwat, 2011), especially his/her international entrepreneurial orientation (Covin \& Miller, 2014) or global mindset (Hagen \& Zuchella, 2014). The basic characteristics of the owner includes four dimensions, namely sex, age, global mindset or knowledge. Rich literature in this field shows great importance of managerial behaviours for the internationalisation, however, Hutzschenreuter, Pedersen and Volverda (2007) postulate to pay more attention to managerial intentionality to internationalise (global mindset), especially in SMEs. Recently, Pla-Barber and Alegre (2014) have investigated into the role of knowledge and learning in internationalisation. Based on their review, it is obvious that knowledge is one of the key factors affecting internationalisation, especially market choices, entry modes. as well as the speed of internationalisation. Although much has been done in this field, but it still needs further and deeper investigations. This is why, this paper aims at exploring these relations and the impact of basic characteristics of the owner on the process of internationalisation.

As a matter of fact, putting all these three dimensions of ownership into one research study seems to be interesting, despite being a unidimensional approach to ownership, but trying to put three separate dimensions together (making a tiny step towards the multidimensional approach to ownership). Additionally, it meets all features of the international entrepreneurship research, which is gradually beginning to emerge as the dominant perspective in international business studies. Furthermore, it seems that this topic is rare in Central and Eastern Europe, including Poland (Puślecki, Staszkow, \& Trąpczyńśki, 2014; Obłój \& Ciszewska-Mlinarič, 2014; Bruton, Ahlstrom, \& Obloj, 2008; Cieślik, Michałek, \& Nasadiuk, 2015). Therefore, the purpose of this study was to examine whether and how ownership impacts on the level of internationalisation. Nevertheless, this article still uses the unidimensional approach to the ownership in 
internationalisation (three various dimensions of ownership are treated separately). The article uses the research sample of 190 internationalised Polish businesses. The survey was conducted in 2014 on a random sample, however, the sample is not representative for the whole Polish business population.

\section{LITERATURE REVIEW \\ Theoretical Framework and Hypotheses Development}

\section{International Entrepreneurship}

A few previous decades have caused that not only the global economy but also the theory of international business have undergone a dramatic change, and the "new economic landscape requires a combination of entrepreneurship, innovation, and internationalization" (Hagen, Denicolai, \& Zuchella, 2014, p. 111). The concept of "international entrepreneurship' (IE) came into being in late 1980s (Kohn, 1988; Morrow, 1988; McDougall, 1989), however, the theory of IE was developed in mid 1990s, mainly by McDougall, who together with Oviatt developed this theory in the following years (Oviatt \& McDougall, 1994; McDougall, Shane, \& Oviatt, 1994; McDougall \& Oviatt, 1996, 2000; Oviatt \& McDougall, 2005). International entrepreneurship has been developing very intensively now (Al-Aali \& Teece, 2014; Almor, Tarba, \& Margalit, 2014; Covin \& Miller, 2014; Hennart, 2014; Wach \& Wehrmann, 2014). International entrepreneurship (Coviello \& Jones, 2004; Coviello, McDougall, \& Oviatt, 2011; Coviello, Jones, \& McDougall-Covin, 2014), linking two research domains - entrepreneurship theory and international business theory (McDougall \& Oviatt, 2000; McDougallCovin, Jones, \& Serapio, 2014; Zucchella \& Sciabini, 2007; Wach \& Wehrmann, 2014), is gradually beginning to emerge as the dominating approach within the internationalisation theory (the leading approach towards business internationalisation process) (Schweizer \& Duxbury, 2010; Vahlne \& Ivarson 2014; Jones, Coviello, \& Tang, 2011; Coviello et al. 2014). International entrepreneurship specifically examines and prioritises the role of the entrepreneur as a key factor in the internationalisation process of the firm, especially of SMEs (Wach, 2015) alongside the external environment and the entrepreneurial process constituting the triad of international entrepreneurship or entrepreneurial internationalisation (lodowska, Pera, \& Wach, 2016).

There are different and numerous approaches towards international entrepreneurship studies. For instance, Hagen and Zuchella (2014) point out four research perspectives. Firstly, studies into a firm-level behaviour of entrepreneurial internationalisation over time exploring timing and speed of the internationalisation process (Jones \& Coviello, 2005). Secondly, studies into international entrepreneurial dynamics enabling to recognise, discover and exploit new business opportunities in an international context (Mathews \& Zander, 2007; Oyson \& Whittaker, 2012). Thirdly, studies combining entrepreneurial internationalisation and corporate life cycle (CLC), which explore behaviour of entrepreneurial firms, especially born globals, at different stages of development (Gabrielsson, Kirpalani, Dimitratos, Solber, \& Zuchella, 2008). Fourthly, the dynamic capabilities perspective is widely used in international entrepreneurship studies (Weerawardena, Mort, Liesch, \& Knight, 2007; Freiling \& Zimmermann, 2014). This approach explains the role of the entrepreneur, the learn- 
ing process as the knowledge is the outcome in the entrepreneurial internationalisation. Of course, we can also support other perspectives to be included. For instance, Hagen and Zuchella (2014) link international entrepreneurship and high-growth entrepreneurship studies, introducing even a new term 'born to run' for high-growth born globals. Another very interesting perspective is linking innovation and international entrepreneurship (Hagen et al., 2014), as innovation is indispensable and a prerequisite for all entrepreneurship studies.

The developments in international entrepreneurship and interlinked international business need to be complemented with parallel and supplementary research streams originated from entrepreneurship theory. Therefore, there is another side of entrepreneurial internationalisation (international entrepreneurship), which is the issue of ownership, understood in three different dimensions, as it was mentioned above.

\section{Ownership Structure and Internationalisation}

The level of ownership in overseas subsidiaries is a crucial issue for researchers in international business (Hennart, 2009). Many aspects of capital control and foreign ownership have been investigated so far, however, recent studies still show that there is no clear consensus.

Ownership structure of foreign affiliates has been one of the main themes in the international business studies worldwide. Fernandez and Nieto (2006) provide empirical evidence that a corporate blockholder supports the internationalisation of SMEs (a sample of 6,000 family SMEs in Spain). Using a sample of 1324 Italian manufacturing SMEs, Cerrato and Piva (2012) provide empirical support that the presence of foreign shareholders positively affects the likelihood of going international. Such a positive relation is clearly illustrated by many research studies around the globe, and it is obvious that international investor provides unique knowledge on international markets (Bartha \& Gubik, 2014; Wach, 2014), making the international commitment much easier, implementing the assumptions of the stages $U$-model of internationalisation (Johanson \& Vahlne, 1997; Johanson \& Wiedersheim-Paul, 1975), especially supporting by the networking (Johanson \& Vahlne, 2009; Gorynia \& Jankowska, 2008) and international links of a foreign investor.

It is worth checking whether such a positive correlation between the foreign ownership and the level of internationalisation occurs in the Polish economy as one of the broadly understood emerging markets, thus the first research hypothesis to be tested in this research study is as follows:

H1: Firms operating in Poland of foreign ownership are more internationalised, measured by TNI (transnationality index), than those of domestic capital only.

\section{Familiness and Internationalisation}

So far, several studies have addressed the issue of family ownership in international entrepreneurship. Sciascia et al. (2012, p. 15) emphasise that the empirical research "results of the role of family ownership in" the phenomenon of international entrepreneurship "are inconsistent". Kontinen and Ojala (2010), as well as Pukall and Calabrò (2014) have prepared recently a review of empirical studies linking familiness and internationalisation, and they concluded that there is no consensus on whether family ownership restrains or facilitates their internationalisation. On the one hand, 
some studies show that family firms are much less internationalised than the others. On the other hand, some studies reveal that familiness positively affects internationalisation. It proves that there is still a research gap and these relations should be still investigated (Wach, 2015).

Zahra (2003) empirically supports the positive influence of family ownership on internationalisation, especially its scale and scope (a sample of 409 manufacturing firms from the USA), while Fernandez and Nieto $(2005$; 2006) show that family ownership negatively influences the internationalisation process measured by export intensity. Cerrato and Piva (2012) empirically confirm that the family involvement negatively influences the likelihood to export $(p<0.05)$, while "the presence of managers from outside the family is positively associated with the firm's choice to enter international markets" (p. 634). There is also another side of this argument, introduced by Sciascia et al. (2012, p. 16), who empirically "confirmed the inverted $U$-shaped relationship between family ownership and international entrepreneurship" (a sample of 1035 family firms from the USA using an online questionnaire). Their data show that "the percentage of family ownership at which international entrepreneurship results at a maximum is $53 \% "$ (p. 22). Based on the database of SMEs listed on the Taiwan Stock Exchange (panel date for 77 firms for the years 2000-2007), Chen, Hsu and Chang (2014) found that high family ownership may promote internationalisation. Majority of researchers from Poland reveal that family-firms are less internationalised than the rest, however, some researchers show that family firms listed on the stock exchange are more internationalised (Daszkiewicz \& Wach, 2014; Wach \& Wojciechowski, 2014).

Merono et al. (2015) suggest that there is an evident need for further investigations disentangling the influence of familiness on internationalisation, thus taking into account the existing knowledge gap, the second research hypotheses to be tested in this research study was as follows:

H2: Familiness of ownership does not affect the internationalisation level, thus there is no difference between family and non-family firms as for TNI average value.

\section{Entrepreneur Characteristics and Internationalisation}

The last but not least dimension of ownership in international entrepreneurship is the entrepreneur-owner, who is a kind of 'a hub and a spoke' in the international entrepreneurship theory and research studies. Most researchers advocate that the entrepreneurowner individual-specific factors, especially these mainly related to characteristics of the entrepreneur, positively impact the entrepreneurial internationalisation process (Ruzzier, Hisrich, \& Antoncic, 2006). According to various prior research studies, these are, for example age, education, and work experience (Terjesen, Acs, \& Audretsch, 2010).

Hutzschenreuter, Pedersen and Volverda (2007) discerned a knowledge gap, which makes them call for paying more attention to managerial intentionality to internationalise, which is also recognised by other researchers as a global mindset (Hagen \& Zuchella, 2014). This issue is especially important in SMEs and international entrepreneurship studies.

Johanson and Vahlne (2009) perceive internationalisation as a process of learning and knowledge accumulation. Recently, many empirical research results linking various aspects of knowledge and internationalisation have been published. Knowledge affects especially market choices, entry modes, as well as the speed of internationalisation. For 
Pla-Barber and Alegre (2014) it is evident that knowledge is one of the key factors affecting internationalisation, and in their editorial they call for further research exploring the exact role of knowledge in the internationalisation process. Ruzzier, Hisrich and Antoncic (2006, p. 490) conclude that entrepreneurial knowledge facilitates the recognition of new opportunities, especially in international markets.

The above mentioned two aspects of the entrepreneur's (owner's / manager's) characteristics are promising in the context of international business, but the classical approach to international entrepreneurship deals also with the basic characteristics of the entrepreneurowner such as his/her sex or age (Ubrežiova, Wach, \& Horvathova, 2008). Ruzzier, Hisrich and Antoncic (2006) emphasise that entrepreneurs and their individual characteristics play an important role in international entrepreneurship and international behaviours of firms, what is more, they state that "we cannot neglect the importance of entrepreneurs, widely recognized as the main variables in SMEs' internationalization" (p. 489), this is why these basic aspects were included in the study presented in this article.

Although much has been done in this field, it still needs further and deeper investigations. This is why, this article aims at exploring these relations and the impact of basic characteristics of the owner on the process of internationalisation. The research hypotheses to be tested in this research study were as follows:

H3: Both international attitude and prior knowledge of the entrepreneur-owner affect the internationalisation level of the investigated firms: the higher values of attitude and knowledge indices, the higher value of TNI.

H4: The age and the sex of the entrepreneur-owner do not affect the level of internationalisation of the investigated firms.

\section{MATERIAL AND METHODS}

In order to collect the empirical material, a quantitative research method was applied (Creswell, 2014; Fowler, 2009). The main research method for non-experimental quantitative research which was applied in this study was the research survey using a questionnaire for data collection "with the intent of generalizing from a sample to a population" (Creswell, 2014, p. 13). The survey was conducted in 2014.

Computer-assisted web interviewing (CAWI) was applied as the main survey method. This means that respondents (usually members of top management teams) answered the questions on their own using an online questionnaire which was password protected. The request to fill in the online questionnaire was sent to approximately 7000 Polish firms via a special dedicated e-mail, followed by a telephone conversation request, and 274 questionnaires were submitted, which means that the response rate was around $4 \%$. Of these, 190 completely filled in questionnaires representing all sixteen regions of Poland were selected for further statistical processing. As mentioned above, the sample consists of 190 internationalised businesses from Poland, representing all sixteen administration regions, however, two regions were overrepresented (Table 1).

Management perceptions of firm-level variables are often used in entrepreneurship research (Naman \& Slevin, 1993), and these perceptions can be obtained from interviews or from surveys using questionnaires. "One potential advantage of perceptual approaches 
is a relatively high level of validity because researchers can pose questions that address directly the underlying nature of a construct" (Lyon, Lumpkin, \& Dess, 2000, p. 1058).

The questionnaire was divided into four parts dedicated to different aspects under investigation, such as (i) the characteristics of the firm; (ii) the characteristics of the top management team; (iii) the characteristics of the industry; and (iv) the patterns of internationalisation.

Some variables were measured on an instrument as a continuous score (e.g. sex, age, number of employees) or discrete scores, while the majority of the questions were measured in categorical ways (e.g. type of the applied strategy) which are connected to nominal variables, including also the interval scale from 1 to 5 of the Likert scale. The investigated top management teams were asked to evaluate (from extremely low to extremely high) their global mindset and knowledge by using five different aspects (motivation to go international, cosmopolitism and international openness, knowledge about international markets, experience in international markets, professional business experience in general).

Table 1. Characteristics of the research sample (in \%)

\begin{tabular}{|c|c|c|c|}
\hline \multicolumn{2}{|c|}{ Size of the Firms } & \multicolumn{2}{|l|}{ Age of the Firms } \\
\hline micro & 23 & 30 and more & 18 \\
\hline small & 23 & $20-29$ & 33 \\
\hline medium-sized & 30 & $19-10$ & 26 \\
\hline large & 24 & 9 and less & 23 \\
\hline \multicolumn{2}{|c|}{ Sector of the Economy } & \multicolumn{2}{|l|}{ Scope of the Firm } \\
\hline $\begin{array}{l}\text { agriculture } \\
\text { industry } \\
\text { service }\end{array}$ & $\begin{array}{r}3 \\
42 \\
55\end{array}$ & $\begin{array}{l}\text { mainly domestic } \\
\text { cross-border } \\
\text { only EU } \\
\text { within and beyond EU }\end{array}$ & $\begin{array}{r}17.6 \\
2.8 \\
16.7 \\
62.9\end{array}$ \\
\hline
\end{tabular}

Source: own study based on a survey $(n=190)$.

Dichotomous variables were used very often to divide the population; however, in other cases dummy variables were used (e.g. traditional vs. rapid internationalisation). Two basic types of variables were applied - single indicators as well as overall assessment indexes. The single indicators were based directly on the questionnaire answers without any changes. On that basis, standardised indicators consisting of a couple of single indicators, i.e. the overall assessment indexes, were applied. Each of the overall assessment indexes was constructed through the sum of values indicated by the respondents for each question, and then it was divided by the sum of maximum values possible to be obtained. Finally, the averaged assessment was obtained, standardised in the interval from 0 to 1 (given in percentage in the interval from 0 to 100).

Based on the literature review, of which brief summary was presented above, the research framework includes three main independent variables (ownership structure, family ownership and the characteristics of the owner), while internationalisation level measured by TNI (transnationality index) is the dependent variable (Figure 1).

The statistical calculations were made by the use of the statistical software Statistica ${ }^{\circledR}$ PL v. 10. In the empirical study, the level of statistical significance (alpha or $\alpha$ ) for statistical hypotheses testing was considered as 0.05 . In addition to the well-known basic descriptive statistics, in order to verify the assumed hypothesis the following interferential statistical tests were applied: multivariate regression, Pearson Chi-square, the Pearson's correlation coefficient (PCC), the regression analysis, the Kruskal-Wallis one-way analysis of variance, one-way ANOVA analysis, as well as the Levene test. 


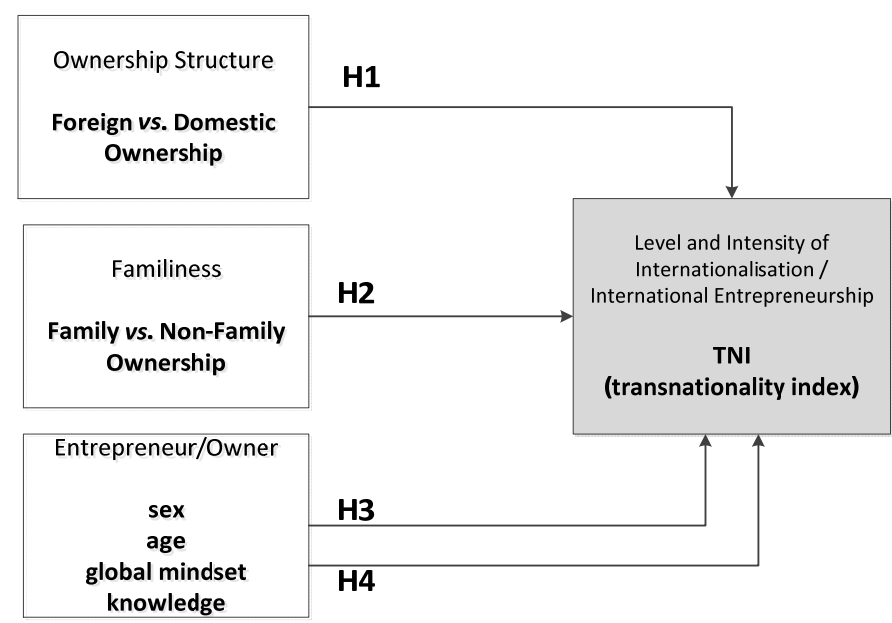

Figure 1. Conceptual research framework of the study Source: own elaboration.

\section{RESULTS AND DISCUSSION}

The transnationality index (TNI) was used as the dependent variable. It is one of the better and universal measures applicable for both SMEs and large companies (Wall, Minocha, \& Rees, 2010; Dunning \& Lundan, 2008; Johnson \& Turner, 2010). TNI index expresses the intensity of investing and localising abroad particular functions and/or operations of the firm. It is calculated as a weighted average of the three shares taking into account the relationship of foreign assets $\left(A_{F}\right)$ to total assets $\left(A_{T}\right)$, foreign sales $\left(S_{F}\right)$ to total sales $\left(S_{T}\right)$ and foreign employment $\left(E_{F}\right)$ to total employment $\left(E_{T}\right)$. This index is expressed as a percentage, and mathematically takes the form:

$$
T N I=\frac{\frac{A_{F}}{A_{T}}+\frac{S_{F}}{S_{T}}+\frac{E_{F}}{E_{T}}}{3} * 100[\%]
$$

The TNI index can reach theoretically values between 0 and 100 , but in the research sample it could reach values between 1 and 100 (usually expressed in \%), whereby 100 means the most internationalised business (in the sample there was no any un-internationalised businesses with the value of 0 ). The values among the investigated businesses varied from 1 to 77.33. The average value was almost 18. Only one fourth of all investigated businesses reached at least 30 . Only one out of ten firms noted more than 50 (the ninth percentile was 49.83).

In the literature it is widely argued and evidenced that small and medium-sized enterprises (SMEs) are usually less internationalised than large companies. Up to a point, the size of the investigated firm matters, nevertheless not statistically significant using the Kruskal-Wallis oneway analysis of variance by ranks $(H[3,190]=2.531450, p=0.469)$, as well as the Mood's median test (Chi-square $=2.521771, \mathrm{df}=3, \mathrm{p}=0.4714$ ). On the whole, large and medium-sized companies are more internationalised ( $\mathrm{TNI}=21.8$ and 20.6 respectively), while the small and micro businesses less, but in a reverse order (12.7 and 15.4 respectively). 


\section{Foreign Ownership}

The Pearson's correlation coefficient $(r=0.42, p=0.000)$ demonstrates the positive average linear relationship between foreign ownership (expressed as $0-100 \%$ ) and the level of internationalisation measured by TNI (expressed as 1-100\%).

To evaluate the relation between the TNI as the dependent variable and the foreign ownership (FO) as the independent variable, the regression analysis was applied. Based on the calculations, we can conclude that the estimated model can explain only about $17.5 \%$ the variability of the original TNI $\left(R^{2}=0.1750\right)$ at the multivariate correlation coefficient $r$ mentioned above. It is rather a low value as $82.5 \%$ of the variance is a random or can be explained by the influence of other, not included in the model, independent variables. Nonetheless, the average difference between the observed values of TNI and the theoretical values amounts to 18.167. The value of $F$ statistics $([1,188], 39.894)$ and the corresponding level of the test probability $p=$ 0.000 confirms statistically significant relationship. What is more, the value of $t$ statistics (6.3162) recounts that the evaluation of the regression coefficient differs significantly from zero. The estimated equation of the regression takes the form of TNI $=12.1595+0.2062 *$ FO. These findings suggest that the increase of 1 p.p. in foreign ownership causes by the increase of 0.2 p.p. in TNI. The results of this study from Poland are in conformity with the above mentioned results from Spain (Fernandez \& Nieto, 2005) and from Italy (Cerrato \& Piva, 2012).

\section{Family Ownership}

Moving to another ownership dimensions, the ANOVA one-way variance was applied to examine whether there is the dependence between the familiness (family versus non-family ownership) and the internationalisation level (TNI). The results of variance analysis ( $F=6.15, p=0.0140$ ) suggest that $T N I$ value is different among family and non-family ownership (the null hypothesis was rejected). Descriptive statistics bring more lights how to interpret the results in details (Table 2). The average internationalisation level of family firms is only $13.79 \%$, while the TNI value for non-family firms is higher and amounts to $20.94 \%$. TNI value exceeds $32.33 \%$ in the case of only $10 \%$ of family firms, whilst the ninth percentile for non-family firms is $63.33 \%$, which simultaneously is the maximum TNI value for family firms. The results from Poland are not surprising, as they are in line with the empirical evidence from Spain (Fernandéz \& Nieto, 2005; 2006) and from Italy (Cerrato \& Piva, 2012).

Table 2. Two-way cross-tabulation for familiness ownership and TNI

\begin{tabular}{|l|l|l|l|l|l|l|l|l|l|}
\hline Age & $\mathbf{N}$ & Mean & Std. Dev. & Std. Err. & Min & Q25 & M & Q75 & Max \\
\hline Non-family firms & 109 & 20.94 & 22.66 & 2.17 & 0 & 0.67 & 12.33 & 38.33 & 77.33 \\
\hline Family firms & 81 & 13.79 & 14.73 & 1,63 & 0 & 1.67 & 9.33 & 23.33 & 63.33 \\
\hline All firms in total & 190 & 17.88 & 17.88 & 1.45 & 0 & 1.00 & 10.00 & 30.00 & 77.33 \\
\hline
\end{tabular}

Source: own study based on a survey $(n=190)$. 


\section{Owner's Characteristics}

Last but not least, the entrepreneur's (owner's) characteristics was taken into special consideration by examining their sex, age, global mindset (attitude towards internationalisation) and knowledge on international markets, anyway three last variables are quantitative.

Regardless of the fact that the correlation between the age of the owner-entrepreneur is statistically nonsignificant, we can conclude that there are no grounds to reject the null hypothesis and the high value of the test probability $(r=0.01, p=0.838)$. Examining the scatterplot may suggest that the value of TNI does not depend on the age of the entrepreneur as the spread of the cases is smooth and even.

As for the owner's sex, which is measured on a nominal scale (male, female), however, $90 \%$ of the sample were men (against $10 \%$ of women), and the respective calculations and especially due to the test probability $(p=0.83)$, there is no presumption against the neutral hypothesis. While there is no significance, it cannot be denied that studying the interaction plot (Figure 2) shows that as a general rule the sex does not impact the internationalisation level among the investigated owners-entrepreneurs, but the sub-samples are not large enough (19 women).

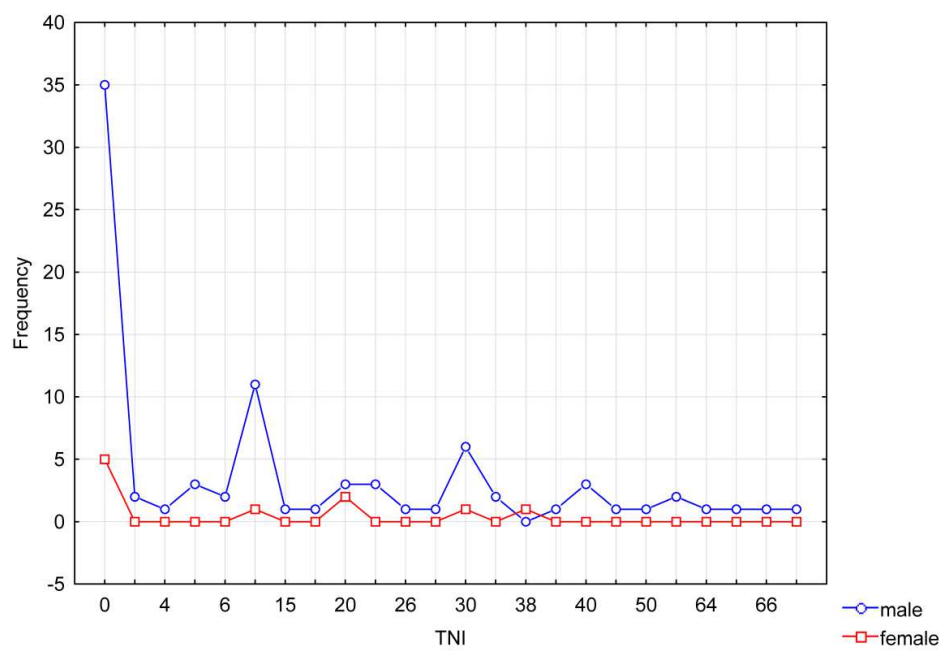

Figure 2. Interaction plot linking the owner's sex and internationalisation level Source: own elaboration based on a survey $(n=190)$.

To characterise the owner-entrepreneur's features, two standardised variables were prepared based on a couple of questions evaluating the attitude and the knowledge on the Likert 5-scale expressed as 0-1 (or 0-100\%). The coefficient $r=0.22$ expresses a weak correlation between the openness to international markets as well as cosmopolitism of the owner and the value of TNI $(p=0.002)$. The scatterplot shows that the TNI is above $50 \%$, whereas the attitude indicator is between 0.8 and 1.0 ( 0 means the lowest openness and cosmopolitism, and 1 the highest), otherwise its value is between 0.15 and 1.0. The coefficient $r=0.09$ $(p=0.212)$ does not lead to the same conclusions. Based on the numbers, it is evident that a larger sample is needed, however, the scatterplot reveals that the TNI values can reach the 
highest values at both very low and very high knowledge and experience in international markets, which can be a bit confusing and difficult to explain or even hard to accept.

\section{Multidimensional ownership}

The first step in the presented research results was to verify unidimensional dependences and relations between the internationalisation and three separate dimensions of ownership. Furthermore, the multidimensional analysis of ownership in internationalisation seems to be interesting as a kind of the novelty. This is why such an attempt at exploring that was made.

Table 3. Multivariate regression linking ownership and TNI

\begin{tabular}{|c|c|c|c|c|}
\hline \multicolumn{5}{|c|}{$\begin{array}{l}\text { Model 1: TNI up to Q1 }(0-1.7> \\
\text { corrected } R^{2}=0.070128 ; F(6,47)=1\end{array}$} \\
\hline dependent variables & $\mathrm{b}$ & std. err. b & $\mathrm{t}$ & $p$-value \\
\hline const & 0.038 & 0.738 & 1.407 & 0.166 \\
\hline foreign ownership & -0.006 & 0.002 & -2.676 & 0.010 \\
\hline family ownership & 0.048 & 0.187 & 0.258 & 0.797 \\
\hline owner's gender & 0.515 & 0.325 & 1.585 & 0.112 \\
\hline owner's age & -0.012 & 0.009 & -1.272 & 0.210 \\
\hline owner's global mindset & -1.394 & 0.781 & -1.785 & 0.081 \\
\hline owner's knowledge & 0.963 & 0.736 & 1.308 & 0.197 \\
\hline \multicolumn{4}{|c|}{ Model 2: TNI up to Q2 (1.7-10> } & $n=41, R^{2}=0.057866$, corrected $R^{2}=-0.108394 ; F(6,34)=0.348044, p=0.906082$ \\
\hline dependent variables & $\mathrm{b}$ & std. err. b & $\mathrm{t}$ & $p$-value \\
\hline const & 7.418 & 4.228 & 1.754 & 0.089 \\
\hline foreign ownership & -0.0245 & 0.030 & -0.7771 & 0.442 \\
\hline family ownership & -0.486 & 0.967 & -0.503 & 0.618 \\
\hline owner's gender & 0.384 & 1.605 & 0.239 & 0.812 \\
\hline owner's age & -0.019 & 0.046 & -0.403 & 0.690 \\
\hline owner's global mindset & -1.266 & 3.606 & -0.351 & 0.728 \\
\hline owner's knowledge & 2.047 & 2.474 & 0.828 & 0.414 \\
\hline \multicolumn{5}{|c|}{$\begin{array}{c}\text { Model 3: TNI up to Q3 }(10-30> \\
n=41, R^{2}=0.146958, \text { corrected } R^{2}=-0.003579 ; F(6,34)=0.976225, p=0.456217\end{array}$} \\
\hline dependent variables & $\mathrm{b}$ & std. err. b & $\mathrm{t}$ & $p$-value \\
\hline const & 10.734 & 10.132 & 1.059 & 0.297 \\
\hline foreign ownership & -0.044 & 0.029 & -1.483 & 0.147 \\
\hline family ownership & -0.016 & 2.1243 & -0.007 & 0.994 \\
\hline owner's gender & -5.194 & 4.568 & -1.137 & 0.263 \\
\hline owner's age & 0.080 & 0.099 & 0.806 & 0.426 \\
\hline owner's global mindset & 12.171 & 8.982 & 1.355 & 0.184 \\
\hline owner's knowledge & 0.805 & 7.733 & 0.104 & 0.918 \\
\hline \multicolumn{5}{|c|}{$\begin{array}{c}\text { Model 4: TNI above Q3 }(30-100> \\
n=41, R^{2}=0.527084, \text { corrected } R^{2}=0.443628 ; F(6,34)=6.315730, p=0.000155\end{array}$} \\
\hline dependent variables & $\mathrm{b}$ & std. err. b & $\mathrm{t}$ & $p$-value \\
\hline const & 7.506 & 14.636 & 0.513 & 0.611 \\
\hline foreign ownership & 0.180 & 0.043 & 4.134 & 0.000 \\
\hline family ownership & -2.917 & 4.076 & -0.716 & 0.479 \\
\hline owner's gender & 3.878 & 5.803 & 0.668 & 0.508 \\
\hline owner's age & 0.145 & 0.142 & 1.015 & 0.317 \\
\hline owner's global mindset & 46.515 & 14.558 & 3.195 & 0.003 \\
\hline owner's knowledge & -25.435 & 11.387 & -2.234 & 0.032 \\
\hline
\end{tabular}

Source: own study based on a survey $(n=190)$. 
Multivariate regression was performed in order to verify the impact of independent variables describing ownership on TNI as a dependent variable. The results of the starting model (model 0) cannot be interpreted as the collection of variables is heteroscedastic (White's test), which means that there are sub-populations that have different variabilities than others. That is why, the answers were divided into four groups according to the level of TNI taking into considerations four quartiles (Table 3). Technically speaking, estimates are unsatisfactory the first group results are difficult to explain and discuss (a minus sign), while there are not proofs for the second and the third group. There are only two clear and significant relations for the most internationalised firms (model 4). The change of foreign ownership and the change of global mindset cause the change of TNI. As for model 1, the least internationalised investigated firms ( $n=54$ ) are managed by the owners with low global mindset (negative impact with a minus sign), so this can be a good explanation why their internationalisation level is low. As for model 4, among the most internationalised investigated firms $(n=41)$ global mindset plays an important role in the internationalisation process and level.

There is no doubt that the attempt to catch multidimensional ownership phenomenon was very welcome and desired indeed, nevertheless there are no sound and broad findings. Even recently published works in highly-ranked journals still deal with the ownership as a unidimensional problem, such as ownership concentration (major shareholder's international preference), ownership structure (state vs. non-state), family ownership. Oesterle, Richta and Fisch (2013, p. 195) support the "cubic stretched u-shaped" relationship between the stake of the largest owner and a firm's international diversification" understood as the international preference of the owner. This result is with line of the result presented in this article that global mindset of owners stimulates internationalisation, but still it is an unidimensional approach. Based on the research of Zhang, Ma, Wang, Li, \& Huo, 2016, the relation between ownership (measured only as state-owned enterprises, SOE and non-state-owned enterprises, none-SOE) and internationalisation was supported, nevertheless no detailed dependencies within the ownership characteristics were supported and shown, as the researchers conclude that "we cannot claim a thorough understanding of the impact of ownership as a boundary condition of our conceptual and empirical knowledge about the internationalization behavior of Chinese SME" (p. 532). D'Angelo, Majocchi and Buck (2016), based on their empirical results, were also able only to make general remarks: family controlled firms are less internationalised than family influenced firms, as well as the role of family managers and external managers is different in these two types of family firms. Also Lin (2012) based on his 772 publicly-listed firms from Taiwan (2000-2008) reports that there is no clear evidence how family impacts the internationalisation. To conclude, unfortunately also results presented in this article suggests that there is still a need to deepen this research problem, nevertheless it clearly illustrates that each step forward, even the attempt presented here, is needed for further studies.

\section{CONCLUSIONS}

All in all, it is apparent from the foregoing arguments that international entrepreneurship is becoming the major approach towards business internationalisation, exploring numerous aspects of international business from the entrepreneurship perspective. The fact of the matter is that many aspects of international business, even those well-grounded in the 
theory of entrepreneurship, are still unexplored in international context (international entrepreneurship). Therefore, this study was designed to explore some links between ownership and international entrepreneurship in Poland.

The initially assumed four research hypotheses $(\mathrm{H} 1, \mathrm{H} 2, \mathrm{H} 3, \mathrm{H} 4)$, due to the calculations and obtained research results, were shaped, slightly changed and extended into five final hypotheses ( $\mathrm{H} 1, \mathrm{H} 2 \mathrm{a}, \mathrm{H} 3 \mathrm{a}, \mathrm{H} 3 \mathrm{~b}, \mathrm{H} 4)$ which were confirmed:

H1: Firms operating in Poland of foreign ownership are more internationalised, measured by TNI, than these of domestic capital only.

confirmed

H2: Familiness of ownership does not affect the internationalisation level, thus there is no difference between family and non-family firms as for TNI average value.

H2a: As a general rule, the investigated non-family firms are more internationalised than family firms as for the average TNI value.

confirmed

H3: Both international attitude and prior knowledge of the entrepreneur- owner affect the internationalisation level of investigated firms: the higher values of attitude and knowledge indi-

$X$ ces, the higher value of TNI.

H3a: International attitude of the entrepreneur-owner affect the level of internationalisation of the investigated firms: the higher values of attitude index, the higher value of TNI.

rejected

confirmed

H3b: The prior knowledge of the entrepreneur-owner concerning international markets affects the internationalisation level of the investigated nonsignificant firms: the higher value of knowledge index, the higher value of TNI.

H4: The age and the sex of the entrepreneur-owner does not affect the level of internationalisation of the investigated firms.

confirmed

The current study and its findings indicate that ownership is one of the key aspects relevant for explaining the internationalisation of firms, but its impact on firms' international behaviour is somewhat equivocal. Based on the survey results and statistical calculations, the following conclusions should be drawn up:

1. The level of internationalisation of the investigated firms is rather moderate, measured by the TNI (on the scale from 1 to 100\%), the average value was almost 18, while only one fourth of the firms exceeded 30 and one of ten firms noted more than 50 . Taking into consideration the fact that the larger economy is, the less open it is, the level of internationalisation of investigated Firms is rather optimistic.

2. Foreign ownership correlates with the level of internationalisation measured by TNI. The more foreign capital in the investigated firms, the more internationalised they are (Pearson's correlation coefficient). What is more, the change of 1 percentage point in TNI is caused by the change of 0.2 percentage point in foreign ownership (regression). Similarly, Anil et al. (2014) more advanced entry modes (direct investment) are facilitated or constrained by the size and multinational experience of the firm and multinationalism, including foreign ownership) stimulates a higher level of internationalisation. 
3. Investigated family firms operating in Poland are less internationalised than their counterparts of general businesses (variance analysis, $F$ test, ANOVA). Similarly, relying on data from a sample of Spanish SMEs, Fernández and Nieto (2006) evidenced that internationalisation is negatively related to family ownership and positively related to corporate ownership. Also Merino and colleagues (2015), on a sample of 500 Spanish firms, found that the family experience positively affect internationalisation. This is partially in line with the results of Cerrato and Piva (2012). Using a sample of Italian SMEs, they evident that the involvement of the owing family negatively influences internationalisation, however, after going international "both the degree of internationalisation and geographical scope in family-managed firms are not significantly different from nonfamily-managed firms" (p. 617).

4. Global mindset understood as the international orientation of the entrepreneur/owner stimulates internationalisation (linear correlation). What is more, it paid a very important role in the most internationalised investigated firms (multivariate regression). The change in TNI is caused by the change of the entrepreneur's / owner's intentionality to go internationalise. Similar results are included in various empirical research and discussed in reviews (Hutzschenreuter, Han, \& Kleindienst, 2010; Hutzschenreuter, Pedersen, \& Volverda, 2007). Using a sample of 121 Polish firms, Ciszewska-Mlinarič (2015) indicates that global mindset is a key capability relevant for explaining the internationalisation, but its impact seems to be somewhat equivocal.

\section{Empirical Limitations}

Like all research, this study is not without some notable limitations. First of all, the research sample is not representative, thus, it is not possible to absolutise the result over the whole population of Polish businesses, however, it illustrates rightly and correctly the situation of firms operating in Poland. Nevertheless, the findings might not be entirely representative. Secondly, the survey and the perceptual approach have their own limitations as they use non-absolute data, nevertheless these techniques are very popular and enable a relatively high level of validity, commonly accepted by researchers worldwide (Lyon et at., 2000).

\section{Future Research Directions}

More studies in this area will be of interest. Firstly, future studies should seek to develop longitudinal research designs. Thus, this is just a preliminary research study. Nonetheless, it would be interesting to have panel data allowing to test entrepreneurial features of international business in more details.

Secondly, as for the owner characteristics, a particularly interesting study should examine entrepreneurial intentions and their antecedents at one point in time. In addition, it would be useful to investigate into the international entrepreneurial orientation (Covin \& Miller, 2014).

Thirdly, linking family ownership and international entrepreneurship in this study design is very preliminary. There is no absolute answer to this question as for example the inverted $U$-shape curve (Sciascia et al., 2012) should be examined in Poland. Doubtless, the role of the family in international entrepreneurship seems to be still unexplored and needs further detailed research studies. 


\section{REFERENCES}

Al-Aali, A., \& Teece, D.J. (2014). International Entrepreneurship and the Theory of the (LongLived) International Firm: A Capabilities Perspective. Entrepreneurship Theory and Practice, 38(1), 95-116. DOI: 10.1111/etap.12077

Almor, T., Tarba, Sh.Y., \& Margalit, A. (2014). Maturing, Technology-Based, Born-Global Companies: Surviving Through Mergers and Acquisitions. Management International Review, 54 - in press, DOI: 10.1007/s11575-014-0212-9

Anil, A., Tatoglu, E., \& Ozkasap, G. (2014). Ownership and market entry mode choices of emerging country multinationals in a transition country: evidence from Turkish multinationals in Romania. Journal of East European Management Studies, 19(4), 413-452.

Bartha, Z., \& Gubik, A.S. (2014). The Role of Business Knowledge in the Internationalisation Process of Hungarian Corporations (chapter 6). In D. Kiendl-Wendner \& K. Wach (Eds.), International Competitiveness in Visegrad Countries: Macro and Micro Perspectives (pp. 125-142). Graz: Fachhochschule Joanneum.

Bruton, G.D., Ahlstrom, D., \& Obloj, K. (2008). Entrepreneurship in emerging markets: where we are today and where we need to move to in the future. Entrepreneurship: Theory and Practice, 32(1), 1-14.

Cerrato, D., \& Piva, M. (2012). The internationalization of small and medium-sized enterprises: the effect of family management, human capital and foreign ownership. Journal of Management \& Governance, 16(6), 617-644. DOI: 10.1007/s10997-010-9166-x

Chen H.-L., Hsu, W.-T., \& Chang, Ch.-Y., (2014). Family Ownership, Institutional Ownership and Internationalization of SMEs. Journal of Small Business Management, 52(4), 771-789.

Cieślik, A., Michałek, J., \& Nasadiuk, I. (2015). Determinants of export performance of Ukrainian firms. Equilibrium. Quarterly Journal of Economics and Economic Policy, 10(3), 91-103. https://doi.org/https://doi.org/10.12775/EQUIL.2015.026

Ciszewska-Mlinarič, M. (2015). Global Mindset and Internationalization of Polish SMEs: Antecedents and Outcomes. Problemy Zarzqdzania, 13(1[2]), 93-113. DOI: 10.7172/1644-9584.51.7

Coviello, N.E., \& Jones, M.V. (2004). Methodological issues in international entrepreneurship research. Journal of Business Venturing, 19(4), 485-508.

Coviello, N.E., Jones, M.V., \& McDougall-Covin, P. (2014). Is International Entrepreneurship research a viable spin-off from its parent disciplines? In A. Fayolle \& P. Riot (Eds.), Institutionalization of Entrepreneurship: Hopes and Pitfalls for Entrepreneurship Research. London, UK: Routledge.

Coviello, N.E., McDougall, P.P., \& Oviatt, B.M. (2011). The emergence, advance and future of international entrepreneurship research - An introduction to the special forum. Journal of Business Venturing, 26(6), 625-631. DOI 10.1016/j.jbusvent.2011.07.002

Covin, J.G., \& Miller, D. (2014). International Entrepreneurial Orientation: Conceptual Considerations, Research Themes, Measurement Issues, and Future Research Directions. Entrepreneurship Theory and Practice, 38(1), 11-44. DOI: 10.1111/etap.12027

Creswell, J.W. (2014). Research Design: Qualitative, Quantitative and Mixed Methods Approaches. Los Angeles, CA: SAGE Publications Inc.

D'Angelo, A., Majocchi, A., \& Buck, T. (2016). External managers, family ownership and the scope of SME internationalization. Journal of World Business, 51(4), 534-547,

Daszkiewicz, N., \& Wach, K. (2014). Motives for Going International and Entry Modes of Family Firms in Poland. Journal of Intercultural Management, 6(2), 5-18.

Dunning J.H., \& Lundan, S.M. (2008). Multinational Enterprises and the Global Economy (2nd ed.). Chelterham-Northampton, MA: Edward Elgar. 
Fernandez, Z., \& Nieto, M.J. (2005). Internationalization Strategy of Small and Medium-Sized Family Businesses: Some Influential Factors. Family Business Review, 18(1), 77-89.

Fernandez, Z., \& Nieto, M.J. (2006). Impact of ownership on the international involvement of SMEs. Journal of International Business Studies, 37(3), 340-351.

Fowler, F.J. (2009). Survey Research Methods (4th ed.). Thousand Oaks, CA: Sage.

Freiling, J., \& Zimmermann, M. (2014). Internal and External Learning Races in 'Born Transnationals': What are the Driving Forces?. Entrepreneurial Business and Economics Review, 2(1), 19-35. http://dx.doi.org/10.15678/EBER.2014.020103

Gabrielsson, M., Kirpalani, M., Dimitratos, P., Solber, C., \& Zuchella, A. (2008). Born globals: propositions to help advance the theory. International Business Review, 17(4), 385-401.

Głodowska, A., Pera, B., \& Wach, K. (2016). International Environment and its Influence on the Entrepreneurial Internationalisation of the Firm: The Case of Polish Businesses. In K. Wach \& A. Żur (Eds.), Advancing Research in Entrepreneurship in Global Context: Conference Proceedings of the 8th ENTRE Conference. Kraków: Cracow University of Economics.

Gorynia, M., \& Jankowska, B. (2008). Clusters - a Useful Concept of Increasing the Internationalization of SMEs. The Case of Furniture, Automotive and Boiler-making Clusters in Poland. Proceedings of the International Conference An Enterprise Odyssey: Tourism, Governance and Entrepreneurship (pp. 1153-1162). Zagreb: University of Zagreb.

Gubik, A.S., \& Bartha, Z. (2014). SMI Internationalisation Index (SMINI) based on the Sample of the Visegrad Countries (chapter 2). In A.S. Gubik \& K. Wach (Eds.), International Entrepreneurship and Corporate Growth in Visegrad Countries (pp. 23-40). Miskolc: University of Miskolc.

Hagen, B., Denicolai, S., \& Zuchella, A. (2014). International entrepreneurship at the crossroads between innovation and internationalization. Journal of International Entrepreneurship, 12(2), 111-114.

Hagen, B., \& Zuchella, A. (2014). Born Global or Born to Run? The Long-Term Growth of Born Global Firms. Management International Review, 54(4), 497-525. DOI: 10.1007/s11575-014-0214-7

Hennart, J.-F. (2009). Down with MNE-centric Theories! Market Entry and Expansion as the Bundling of MNE and Local Assets. Journal of International Business Studies, 40(9), 1432-1454.

Hennart, J.-F. (2014). The Accidental Internationalists: A Theory of Born Global. Entrepreneurship Theory and Practice, 38(1), 117-135. DOI: 10.1111/etap.12076

Hutzschenreuter, T., Han, U.-S., \& Kleindienst, I. (2010). Exploring the role of managerial intentionality in international business. In T. Devinney, T. Pedersen \& L. Tihanyi (Eds.), The Past, Present and Future of International Business \& Management (Advances in International Management, Volume 23, pp. 113-135). Emerald Group Publishing Limited.

Hutzschenreuter, T., Pedersen, T., \& Volverda, H.W. (2007). The role of path dependency and managerial intentionality: A perspective on international business research. Journal of International Business Studies, 38(7), 1055-1068.

Johanson, J., \& Vahlne, J.-E. (1977). The Internationalization Process of the Firm: A Model of Knowledge Development and Increasing Foreign Commitments. Journal of International Business Studies, 8(1), 23-32.

Johanson, J., \& Vahlne, J.-E. (2009). The Uppsala Internationalization Process Model Revisited: From Liability of Foreignneess to Liability of Outsidership. Journal of International Business Studies, 40(9), 1411-1431.

Johanson, J., \& Wiedersheim, P. (1975). The internationalisation of the firm: Four Swedish cases. Journal of Management Studies, 12(3), 305-322.

Johnson, D., \& Turner, C. (2010). International Business. Themes and Issues in the Modern Global Economy (2nd ed.). Oxon - New York, NY: Routledge. 
Jones, N.V., \& Coviello, N. (2005). Internationalisation: conceptualising an entrepreneurial process of behaviour in time. Journal of International Business Studies, 36(2), 227-244.

Jones, N.V., Coviello, N., \& Tang, Y.K. (2011). International Entrepreneurship Research (1989-2009): A Domain Ontology and Thematic Analysis. Journal of Business Venturing, 26(6), 632-659.

Kohn, T.O. (1988). International Entrepreneurship: Foreign Direct Investment by Small U.S.-based Manufacturing Firms. Unpublished DBA Thesis, Harvard University, Ann Arbor, MI (university microfilms).

Kontinen, T., \& Ojala, A. (2010). The Internationalization of Family Businesses: A Review of Extant Research. Journal of Family Business Strategy, 1, 97-107.

Kurek, S., \& Rachwał, T. (2011). Development of entrepreneurship in ageing populations of The European Union. Procedia. Social and Behavioral Sciences, 19, 397-405.

Larimo, J., \& Arslan, A. (2013). Determinants of foreign direct investment ownership mode choice: Evidence from Nordic investments in Central and Eastern Europe. Journal of East European Management Studies, 18(2), 232-263.

Lin, W.-T. (2012). Family ownership and internationalization processes: Internationalization pace, internationalization scope, and internationalization rhythm. European Management Journal, 30(1), 47-56.

Lyon, D.W., Lumpkin, G.T., \& Dess, G.G. (2000). Enhancing Entrepreneurial Orientation Research: Operationalizing and Measuring a Key Strategic Decision Making Process. Journal of Management, 26(5), 1055-1085. DO: 10.1177/014920630002600503

Mathews, J., \& Zander, I. (2007). The international dynamics of accelerated internationalisation. Journal of International Business Studies, 38(3), 387-403.

McDougall, P.P. (1989). International versus Domestic Entrepreneurship: New Venture Strategic Behavior and Industry Structure. Journal of Business Venturing, 4(6), 387-400. DOI: 10.1016/0883-9026(89)90009-8

McDougall, P.P., \& Oviatt, B.M. (1996). New Venture Internationalization, Strategic Change, and Performance: A Follow-up Study. Journal of Business Venturing, 11(1), 23-42. DOI: 10.1016/0883-9026(95)00081-X

McDougall, P.P., \& Oviatt, B.M. (2000). International Entrepreneurship: The Intersection of Two Research Paths. The Academy of Management Journal, 43(5), 902-906. DOI: 10.2307/1556418

McDougall, P.P., Shane, S., \& Oviatt, B.M. (1994). Explaining the Formation of International New Ventures: The Limits of Theories from International Business Research. Journal of Business Venturing, 9(6), 469-487. DOI: 10.1016/0883-9026(94)90017-5

McDougall-Covin, P., Jones, M.V., \& Serapio, M.G. (2014). High-Potential Concepts, Phenomena, and Theories for the Advancement of Entrepreneurship Research. Entrepreneurship Theory and Practice, 38(1), 1-10. DOI: 10.1111/etap.12090

Merono, F., Monreal-Pérez, J., \& Sánchez-Marin, G. (2015). Family SMEs' Internationalisation: Disentangling the Influence of Familiness on Spanish Firms' Export Activity. Journal of Small Business Management, 53(4), 1164-1184. DOI: 10.1111/jsbm.1211

Morrow, J.F. (1988). International entrepreneurship: A new growth opportunity. New Management, 3(5), 59-61.

Naman, J.L., \& Slevin, D.P. (1993). Entrepreneurship and the concept of fit: A model and empirical tests. Strategic Management Journal, 14(2), 137-153. DOI: 10.1002/smj.4250140205.

Obłój, K., \& Ciszewska-Mlinarič, M. (2014). Systemic effects of internationalization of Polish companies. In G. Kołotko (Ed.), Management and Economic Policy for Development, Chapter: Systemic effects of internationalization of Polish firms (pp.73-94). NY, US: Nova Publishers.

Oesterle, M.-J., Richta, H.N., \& Fisch, J.H. (2013). The influence of ownership structure on internationalization. International Business Review, 22(1), 187-201. 
Oviatt B.M., \& McDougall, P.P. (1994). Towards a Theory of International New Ventures. Journal of International Business Studies, 25(1), 44-64.

Oviatt, B.M., \& McDougall, P.P. (2005). Defining international entrepreneurship and modeling the speed of internationalization. Entrepreneurship Theory and Practice, 29(5), 537-553

Oyson, M., \& Whittaker, D.W. (2010). An Opportunity-Based Approach to International Entrepreneurship: Pursuing Opportunities Internationally through Prospection. In Proceedings of the 18th Annual High Technology Small Firms Conference. May 27-28, 2010, The Netherlands.

Pla-Barber, J., \& Alegre, J. (2014). The role of knowledge and learning in internationalization. International Business Review, 23(1), 1-3. DOI: 10.1016/j.ibusrev.2013/09.05

Pukall, T.J., \& Calabrò, A. (2014). The Internationalization of Family Firms: A Critical Review and Integrative Model. Family Business Review, 27(2), 103-125. DOI: 10.1177/0894486513491423

Puślecki, Ł., Staszków, M., \& Trąpczyńśki, P. (2014). International Business Research in Poland: Critical Review of Selected Publications. Studia Negotia, 59(2), 5-24.

Ruzzier, M., Hisrich, R.D., \& Antoncic, B. (2006). SME internationalization research: past, present, and future. Journal of Small Business and Enterprise Development, 13(4), 476-497. DOI: 10.1108/14626000610705705

Schweizer, R., Vahlne, J.-E., \& Johanson, J. (2010). Internationalization as an Entrepreneurial Process. Journal of International Entrepreneurship, 8(4), 343-370.

Sciascia, S., Mazzola, P., Astrachan, J.H., \& Pieper, T.M. (2012). The role of family ownership in international entrepreneurship: exploring nonlinear effects. Small Business Economics, 38, 15-31. DOI 10.1007/s11187-010-9264-9

Terjesen, S.A., Acs, Z.J., \& Audretsch, D.B. (2010). International Business, Entrepreneurship and the Global Economy (chapter 16). In Z.J. Acs \& D.B. Audretsch (Eds.), Handbook of Entrepreneurship Research: An Interdisciplinary Survey and Introduction (International Handbook Series on Entrepreneurship, Vol. 5, 2nd. ed). New York - Heidelber: Springer. DOI: 10.1007/978-1-4419-1191-9_16

Ubrežiová, I., Wach, K., \& Horváthová, J. (2008). Entrepreneurship in small and medium-sized enterprises: Comparative study between Slovakia and Poland for the years 2001-2007. Agricultural Economics, 54(8), 358-366.

Vahlne, J.-E., \& Ivarsson, I. (2014). The globalization of Swedish MNEs: Empirical evidence and theoretical explanations. Journal of International Business Studies, 45(3), 227-247.

Wach, K. (2014). The Role of Knowledge in the Internationalisation Process: An Empirical Investigation among Polish Businesses (chapter 7). In D. Kiendl-Wendner \& K. Wach (Eds.), International Competitiveness in Visegrad Countries: Macro and Micro Perspectives (pp. 143-158). Graz: Fachhochschule Joanneum.

Wach, K. (2015). Incremental versus Rapid Internationalisation of Firms: Results of Exploratory Investigation from Poland. Entrepreneurial Business and Economics Review, 3(4), 37-48. http://dx.doi.org/10.15678/EBER.2015.030403

Wach, K., \& Wehrmann, C. (2014). Entrepreneurship in International Business: International Entrepreneurship as the Intersection of Two Fields (chapter 1). In A.S. Gubik \& K. Wach (Eds.), International Entrepreneurship and Corporate Growth in Visegrad Countries (pp. 9-22). Miskolc: University of Miskolc.

Wach, K., \& Wojciechowski, L. (2014). The Size and the Strategic International Orientation: The Use of EPRG Model among Polish Family and Non-Family Firms. Przedsiębiorczość $i$ Zarzqdzanie, XV(7[1]), 143-156.

Wall, S., Minocha, D., \& Rees, B. (2010). International Business (3rd ed.). Harlow-Essex: Prentice Hall. 
Weerawardena, J., Mort, G., Liesch, P., \& Knight, G. (2007). Conceptualizing accelerated internationalization in the born global firm: a dynamic capabilities perspective. Journal of World Business, 42(3), 294-306.

Wiklund, J., Nordqvist, M., Hellerstedt, K., \& Bird, M. (2013). Internal versus External Ownership Transition in Family Firms: An Embeddedness Perspective. Entrepreneurship Theory and Practice, 37(6), 1319-1340.

Zahra, S.A. (2003). International expansion of U.S. manufacturing family business: The effect of ownership and involvement. Journal of Business Venturing, 18(4), 495-512.

Zhang, X., Ma, X., Wang, Y., Li, X., \& Huo, D. (2016). What drives the internationalization of Chinese SMEs? The joint effects of international entrepreneurship characteristics, network ties, and firm ownership. International Business Review, 25(2), 522-534.

Zucchella, A., \& Scabini, P. (2007). International Entrepreneurship - Theoretical foundations and Practice. New York: Palgrave Macmillan. 


\section{Author}

\section{Krzysztof Wach}

Associate Professor of the Cracow University of Economics (Poland) - director of the Department of International Trade. Habilitated doctor of economics (DEcon), PhD in management, specialist in international entrepreneurship, author of several books and over 150 scientific articles, editor-inchief of the scientific quarterly 'Entrepreneurial Business and Economics Review' (Poland) and the scientific biannual 'International Entrepreneurship' (Poland), member of editorial boards of several scientific journals, including 'Journal of Management and Business Administration Central Europe' (Poland), 'Society and Economy' (Hungary), 'Theory - Methodology - Practice' (Hungary), 'Central European Review of Economics \& Finance' (Poland), 'Business Excellence' (Croatia), 'Studia Negtia' (Romania), 'Entrepreneurship - Education' (Poland); in the years 2012-2017 an OECD and the European Commission national expert for entrepreneurship, participant of various international education and research projects (e.g. Jean Monnet, Atlantis, International Visegrad Fund IVF, Central European Initiative $\mathrm{CEI}$ ), visiting professor in various American and European universities, including Grand Valley State University (Grand Rapids, USA), Roosevelt University (Chicago, USA), University of Detroit Mercy (Detroit, USA), Loyola University Chicago (Chicago, USA), Northumbria University (Newcastle, UK), University College London (UK), Technical University of Cartagena (Cartagena, Spain), Fachhochschule Joanneum (Graz, Austria), University of Zagreb (Croatia), Shanghai Lixin University of Accounting and Finance (China). Since 2017, he has been a Research Fellow of Futures Entrepreneurship Centre, at the Plymouth University, UK and a Visiting Scholar of the Faculty of Economics and Business, University of Zagreb (2017-2019). He is also a member of the Academy of International Business (AIB) - Executive Board of AIB-CEE Chapter vice-chair for programme 2018, and the member of European International Business Academy (EIBA).

Correspondence to: Prof. UEK, dr hab. Krzysztof Wach; Cracow University of Economics; Faculty of Economics and International Relations; Department of International Trade; ul. Rakowicka 27, 31-510 Kraków, Poland; e-mail: wachk@uek.krakow.pl

\section{Acknowledgements and Financial Disclosure}

This article came into being within the research project entitled "Behaviour of Polish Firms in the Process of Internationalisation from the International Entrepreneurship Perspective" (OPUS 4) which has been funded by the National Science Centre of Poland on the basis of the decision no. DEC-2012/07/B/HS4/00701 in the years 2013-2018. Many thanks to the anonymous reviewers for their valuable comments, especially to a statistics editor $\mathrm{dr}$. Agnieszka Wałega for an excellent editing of this article.

\section{Copyright and License}

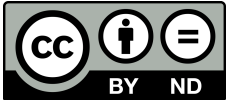

This article is published under the terms of the Creative Commons

Attribution - NoDerivs (CC BY-ND 4.0) License

http://creativecommons.org/licenses/by-nd/4.0/

\section{Published by the Centre for Strategic and International Entrepreneurship - Krakow, Poland}

